\title{
REPERTORIO BIBLIOGRÁFICO SOBRE ORIENTACIÓN Y MÉTODO DEL DERECHO CONSTITUCIONAL
}

\author{
JORGE ALGUACIL GONZÁLEZ-AURIOLES \\ Profesor de Derecho Constitucional \\ UNED \\ FERNANDO REVIRIEGO PICÓN \\ Profesor de Derecho Constitucional \\ UNED
}

\section{NOTA PRELIMINAR}

La elaboración de cualquier repertorio bibliográfico supone una tarea de búsqueda y confrontación de materiales que encierra a veces dificultades. Sin embargo, éstas crecen cuando la primera cuestión es determinar el propio alcance del Repertorio. Puede ser prudente entonces realizar unas previas aclaraciones que expliquen las razones que nos mueven a decir que un determinado trabajo centra su análisis en lo que denominamos a estos efectos orientación y método de nuestra asignatura.

Si por orientación entendemos el acto de colocar o ubicar una cosa en posición determinada respecto los puntos cardinales, podríamos incluir dentro de este específico apartado todos aquellos trabajos que centran su objeto de análisis en explicar cómo se sitúa nuestra disciplina científica entre el resto de las ciencias del saber y en concreto entre el resto de las disciplinas jurídicas. En general, son trabajos que se refieren al contenido específico de nuestra asignatura, a la naturaleza singular de sus normas, a la importancia que tiene en nuestra disciplina el componente histórico y valorativo, en fin, a la relevancia que comporta para la formación del estudiante el aprendizaje del Derecho constitucional. 
El Diccionario de la Real Academia de la Lengua Española nos dice que por método debemos entender el modo de decir o hacer con orden una cosa; esto aplicado al mundo de las ciencias implica, como explica el mismo diccionario, el procedimiento que se sigue para hallar la verdad y enseñarla. Dentro del apartado que lleva por denominación método incluimos pues todos aquellos estudios que centran sus análisis en explicar cómo se va a investigar o explicar la específica materia del Derecho constitucional; o dicho de otro modo, qué procedimiento se va a seguir para comprender la disciplina y enseñarla.

A estas breves consideraciones hemos de añadir al menos tres observaciones. En primer lugar, es clásico el debate sobre si el método constituye el objeto y la orientación de la disciplina o si es el objeto el que predetermina el método. En cualquier caso, parece necesario insistir en la íntima relación entre la orientación y el método; se trata de dos aspectos íntimamente relacionados. Por eso hemos preferido estructurar el repertorio no en función de estas dos categorías sino usando un criterio cronológico. Quizá éste condiciona de una forma muy concreta las diversas aportaciones que versan sobre esta materia; así, agrupamos en primer lugar aquellos estudios publicados antes de 1900, fecha en la que, como se sabe, la disciplina de Derecho constitucional se escinde de la de Derecho administrativo; posteriormente, aquellos publicados entre esta fecha y el final de la Segunda República, aun cuando quizá pudiéramos singularizar aquellos publicados durante el periodo republicano. El régimen dictatorial del General Franco abarca un período de inexistencia de Constitución en el que también se producen aportaciones científicas significativas; el último período comprende desde el surgimiento de la Constitución de 1978 como Constitución normativa hasta nuestros días. Por último, hemos incluido una sección que recoge semblanzas de profesores y estudiosos de nuestra asignatura; desde el convencimiento de que a través de estas semblanzas se puede alcanzar a comprender las diferentes orientaciones de nuestra disciplina a lo largo de la historia.

En segundo lugar, sólo citaremos doctrina española de Derecho constitucional o más ampliamente de Derecho político. No podemos recoger todas aquellas aportaciones clásicas que desde diversas perspectivas y distintas tradiciones culturales han influido de forma notable en la orientación y método de nuestra disciplina en España. Así, prescindiendo del clásico constitucionalismo decimonónico, es evidente la difusión en España de las aportaciones de la dogmática alemana, desde Jellinek, Triepel, Schmitt, Heller, Smend y Kelsen hasta más recientemente Hesse y Böckenförde; otros autores españoles han recibido preferentemente una inspiración italiana (de Orlando, Santi Romano o Costantino Mortati a Esposito, Crisafulli, Tosato, Lavagna, Pace, Zagrebelsky y tantos otros), o francesa (de Hauriou, Esmein, Duguit o Carré de Malberg hasta M. Favoreu, pasando por M. Duverger). En menor medida, al menos hasta tiempos recientes, también ha desempeñado un papel la doctrina anglosajona (sea mediada por los alemanes Friedrich o Loewenstein, sea directamente desde los clásicos Bagehot, Bryce, Dicey, Blackstone a Posner, Rawls, Hart o Dworkin). 
Por último, parece necesario llamar la atención al lector de que sin ser una selección lo que le presentamos, tampoco pretendemos lograr un panorama exhaustivo de cuanto se ha escrito sobre orientación y método de nuestra asignatura. Y ello por una razón muy sencilla: porque en muchos casos estos temas ni siquiera se han publicado, o si se ha hecho, se ha realizado conjuntamente con la materia sustantiva de análisis del estudio en cuestión, lo que complica, hasta a veces hacerlo imposible, su extracción.

\section{ORIENTACIÓN Y MÉTODO DE NUESTRA ASIGNATURA ANTES DE 1900}

Alcalá Galiano, a.:

- "Lección primera", Lecciones de Derecho Político constitucional, Imprenta de Boix, Madrid, 1843 (puede consultarse la edición publicada por el Centro de Estudios Constitucionales, Madrid, 1984).

AlLER, D.E.:

- Exposición elemental de Derecho Político, Victoriano Suárez, Madrid, 1875.

COlmeiro, M.:

- "Prólogo", Derecho Político según la bistoria de León y Castilla, Imp. Fermín Martínez García Madrid, 1873

- "Derecho Político. Capítulo II. Del derecho político", Elementos de Derecho Político y Administrativo de España, Libreria de D. Angel Calleja, 1858.

CuAdRA, A.M. DE LA:

- "Principios de Derecho Político. Lección 1. De la existencia del derecho político: diferencia entre el mismo y el público", Principios de Derecho Político acomodados a las enseñanzas de las Universidades y seguidos de un ligero comentario a la Constitución actual de España, Sevilla, 1853.

Cunsta Martín, S.:

- "Principios fundamentales del Derecho Político. Idea de Derecho Político y naturaleza de sus leyes", Elementos de Derecho Político, F. Nuñez, Salamanca, 1877.

DE la CuAdra, A.M.:

- Principios de Derecho Político acomodados a las enseñanzas de las universidades y seguidos de un ligero comentario a la Constitución actual de España, Imprenta F. Lis y Vázquez, Sevilla, 1853.

Díez De RiBera, I.:

- Instalación de la cátedra de la Constitución política de la monarquía española en la ciudad de Valencia a cargo del pavorde don Nicolás Gareli, Imprenta de Manuel Muñoz y Compañía, Valencia, 1820.

DONOSO CORTES, J.:

- Lecciones de Derecho Político, Imprenta de la Compañía Tipográfica, Madrid, 1837 (puede consultarse la edición publicada por el Centro de Estudios Constitucionales, Madrid, 1984 o, también, en Obras completas, La Editorial Católica, Madrid, 1946). 
ESPERÓN, A,

- "Introducción", Derecho Político Constitucional de España, José M. Alonso Madrid, 1854.

FERRÁN, I. M. DE,

- Introducción sobre el orden lógico en el plan general de su enseñanza, y el modo de estudiar con provecho las diferentes partes y materias que abraza", Extracto metódico de un Curso completo de Derecho Político y Administrativo redactado con estricta sujeción al programa de su exposición y examen y a la vigente legislación politico-administrativa de España, Jaime Jepús, Barcelona, 1873.

García LunA, T.:

- "Lecciones de Derecho Político por Don Antonio Alcalá Galiano", Revista de Madrid, 1846.

Gil y RoBles, E,

- "Prólogo", Tratado de Derecho Político según los principios de la Filosofía y Derecho cristianos, Imprenta Salmanticense, Salamanca, 1899 (puede consultarse la edición publicada por Afrodisio Aguado, Madrid, 1961).

GINER DE LOS Ríos:

- Principios de Derecho Político, Madrid, 1884

LÁZARO DE DOU y BASSOLS, R.:

- "Prólogo del autor", Instituciones de derecho público general de España con noticias del particular de Cataluña y de las principales reglas de gobierno en cualquier estado, Benito García, Madrid, 1800.

LEÓN OlabieTA, F. DE:

- Observaciones acerca del método que debe emplearse en el estudio de la ciencia del Derecho, Imp. de J. Domenech, Valencia,1871.

Mellado, F.:

- "Preliminar. Idea general de la materia. Método y plan de la obra", Tratado elemental de Derecho Político, G. Hernández, Madrid, 1891.

Oloriz MARTínez, R.:

- "Nociones preliminares (objeto de conocimiento y formación del conocimiento científico)", "Derecho Político", "Arte del derecho político", "Relaciones del derecho político con la política", Estudios de Derecho Politico: resumen de algunas lecciones explicadas a los alumnos, Imp. Domenech, Valencia, 1897.

ORODEA, P.M.:

- "Prólogo", Elementos de Derecho político constitucional aplicado a la Constitución política de la Monarquía española de 1837, Imprenta de Pita, Madrid, 1843.

PACHECO, J.F.:

— "Lección primera", Lecciones de Derecho Politico Constitucional pronunciadas en el Ateneo de Madrid en 1844-1845, Imprenta de Boix, 1845 (puede consultarse la edición publicada por el Centro de Estudios Constitucionales, Madrid, 1984). 
POSADA, A.:

- Guía para el estudio y aplicación del Derecho Constitucional de Europa y América, Sucesores de Rivadeneyra, Madrid, 1894.

— "Preliminar de la primera edición", Tratado de Derecho Político, Librería de Victoriano Suárez, Madrid,1893.

Ríos, J.M DE LOS.:

- "Introducción", Derecho Político General Español y Europeo, Ignacio Boix, Madrid, 1845.

Rodríguez DE CEPEDA, A.:

- "Capítulo I. Nociones preliminares. Origen y naturaleza de la sociedad. De la soberanía. Idea del derecho político", Elementos de Derecho Público español, Imprenta de López y Cía., Valencia, 1842.

SALAS, R.:

— «Tomo I. Parte Primera. Lección I. ¿Qué se entiende por Derecho Público Constitucional?" Lecciones de Derecho Público constitucional para las escuelas de España, Imprenta del Censor, Madrid, 1821 (puede consultarse la edición publicada por el Centro de Estudios Constitucionales, Madrid, 1982).

Santamaría De Paredes, V.:

- "Del Derecho Político", Curso de Derecho Político según la Filosofía política moderna, la bistoria general de España y la legislación vigente, Imprenta de Ferrer de Orga, Valencia, 1880- 81 (puede consultarse una edición reciente publicada por Analecta, Pamplona, 2004).

SERRANO, L.:

— "Introducción", Estudios sobre el régimen constitucional, J. Peña, Madrid, 1876.

VALDEMOROS, M.:

- Instalación de la cátedra de Constitución en la ciudad de Valencia a cargo del pavorde don Nicolás Gareli, Imprenta patriótica del Pueblo Soberano, Valencia, 1814.

VICO:

- "Título Preliminar. Capítulo I. Concepto del Derecho. Capítulo II. Divisiones del Derecho", Estudios Elementales de Derecho politico y administrativo del Estado español, J. de los Reyes, Granada, 1879.

2. Orientación y método de nUeStra ASignATURA Desde 1900 Hasta EL FinAl de la SEgunda República

AYALA, F:

— "Introducción", SchmitT, C, Teoría de la Constitución, Madrid, 1934.

ELORRIETA, T.:

- "Prólogo", Tratado elemental de Derecho Político comparado. Teoría General del Estado moderno y su Derecho Constitucional, Reus, Madrid, 1916. 
GonzÁlez Posada, A,

- "La nueva orientación del Derecho Político. Estudio preliminar", Duguit, L, La transformación del Estado, Madrid, 1910

LLORENS Y CLARIANA,

- La autonomía en la integración política, Imprenta Helénica, Madrid, 1931.

PÉREZ SERRANO, N:

- La Constitución española (9 de diciembre de 1931) (Antecedentes, textos, comentarios), Editorial Revista de Derecho Privado, Madrid, 1932.

POSADA, A.:

- La crisis del Estado y el Derecho Político, C. Bermejo Impresor, Madrid, 1934.

- El Derecho Político como espectáculo (cincuenta años de cátedra), 18831933, Tip. de Archivos, Madrid, 1933.

- Hacia un nuevo Derecho Político, Páez, Madrid, 1931.

- "Introducción. El Derecho Político. Capítulo III. El Derecho, el Derecho Político y la teoría del Estado", Tratado de Derecho Político (2a edición, Victoriano Suárez, 1915 - 5 edición, Victoriano Suárez, 1935; puede consultarse una edición reciente publicada por Comares, Barcelona, 2003).

- "La nueva orientación del Derecho Político", Estudio introductorio a Duguit, L., La transformación del Estado, José Blass y Cia., Madrid, 1909.

- Derecho Político Comparado, Librería de Victoriano Suárez, Madrid,1906.

Ríos, F. DE,

- "Prólogo", Jellinek, G, Teoría del Estado, Librería General de Victoriano Suárez, Madrid, 1914.

Ruiz del Castillo, C.:

- Manual de Derecho Político, Reus, Madrid, 1939.

- Derecho Político, Madrid, 1934.

- "Estudio preliminar del traductor", Hauriou, M, Principios de Derecho público y constitucional, Reus, Madrid, 1927 (puede consultarse una edición reciente publicada por Comares, Barcelona, 2003).

SANTAMARÍA DE PAREDES, V.:

- Curso de Derecho político según la filosofía política moderna, la bistoria general de España y la legislación vigente ( 6 a edición, Ricardo Fé, Madrid, 1903 - 9a edición, 1913).

VAlle Pascual, L.:

- Introducción general. El Derecho Político como ciencia. Concepto y sistematización. Método y fuentes", Derecho político (orientación sistemática y sintética para la cátedra y seminario), Tip. E. Berdejo, Zaragoza, 1932.

3. ORIENTACiÓN Y MÉTODO DE NUESTRA ASIGNATURA DURANTE LA DICTADURA FRANQUISTA.

AJA FERnÁNDEZ, E.:

— "Prólogo", Lasalle, F, ¿Qué es una Constitución?, Ariel, Barcelona, 1976. 
CARro MarTínez, A.:

- Derecho Político, Universidad de Madrid, Madrid, 1959

CONDE, F.J.:

- Introducción al Derecho Político Actual, Ed. Escorial, Madrid, 1942.

- Escritos y fragmentos políticos, 2 vols., Instituto de Estudios Políticos, Madrid, 1974.

ELÍAs DE TEJADA, F.:

- Contribución al Derecho Público nacional sindicalista, Sevilla, 1939.

- "Derecho Político", Nueva Enciclopedia Jurídica vol. 1, Barcelona, 1950.

Fernández CARVAJAL, R:

- "Las Leyes Fundamentales como instrumento de pedagogía nacional", FrAGa, ; Velarde; Del Campo, la España de los Años Setenta, vol III, Tomo I, Madrid, 1974.

- La crisis del Estado. Estudios de la Teoría del Estado contemporáneo, Madrid, 1958.

FERRANDO BADÍA, J.:

- Estudios de Ciencia Política, Tecnos, Madrid, 1976.

FRAGA IRIBARNE, M.:

- "El método en Teoría del Estado y Derecho constitucional: Una interpretación sociológica", Estudios Sociológicos vol 1 (también publicado en La crisis del Estado, Aguilar, Madrid, 1955).

Fraile Clivillés,

- Introducción al Derecho Constitucional Español, Madrid, 1975.

García de Vercher, R., Lagüens Marquesan, G.:

- Política y Derecho. Introducción al Derecho constitucional y comparado, Imp. Alba, Madrid, 1962.

García Pelayo, M.:

- "Derecho Constitucional", Nueva Enciclopedia Jurídica, Seix, Barcelona, 1950 (todos sus trabajos en Obras completas, Centro de Estudios Constitucionales, Madrid, 1991).

- "Derecho Público", Nueva Enciclopedia Jurídica, Seix, Barcelona, 1950.

- Derecho Constitucional Comparado, Revista de Occcidente, Madrid, 1950.

- "Constitución y Derecho Constitucional (evolución y crisis de ambos conceptos)", Revista de Estudios Políticos, vol. XX, 1948.

González CASANOva, J.A.:

- Comunicación humana y comunidad política. Una aproximación al Derecho Político, Tecnos, Madrid, 1968.

GuASP, J.:

- "El Derecho Político como Derecho del Gobierno", Homenaje a Nicolás Pérez Serrano, Tomo II, Reus, Madrid, 1959.

IZAGA, L:

- "Concepto de Derecho político", Elementos de Derecho Político, tomo I, Bosch, 1952 
JIMÉNEZ DE PARGA, M:

- "Parte primera", Los regímenes políticos contemporáneos, Tecnos, Madrid, 1960 (última edición: Tecnos, Madrid, 1983).

LOJENDIO, I.M,

— Régimen político del Estado español, Bosch, Barcelona, 1942

LuCAS VERDú, P:

- "Derecho Político y transformación política española", Revista de la Facultad de Derecho de la Universidad Complutense, n 55, 1979.

- "Lugar de la Teoría de la Constitución en el marco del Derecho Político", Revista de Estudios Políticos, n 188, 1973.

- Curso de Derecho Político, Tecnos, Madrid, 1972.

- "Situación de la Ciencia del Derecho Político en España", Anuario de Ciencia Política, 1, 1971.

- "En torno al problema conceptual del Derecho Político", Boletín Informativo del Seminario de Derecho Político. Universidad de Salamanca, $\mathrm{n}^{\circ}$ 32, 1964.

- "Introducción al Derecho Político. Las transformaciones sociales del Derecho Político actual", (Prólogo de Enrique Tierno Galván), Publicaciones del Real Colegio de España en Bolonia, Bosch, Barcelona, 1958

"El horizonte iusnaturalista del Derecho constitucional occidental", Revista de Estudios Políticos n ${ }^{\circ}$ 94, 1957

- "La historia de las ideas políticas y su función en el ámbito de la ciencia del Derecho Político", Boletín Informativo del Seminario de Derecho Político, Universidad de Salamanca no 13-15, 1956/1957.

— "Recensión a M. Fraga Iribarne, "El método en Teoría del Estado y Derecho constitucional: Una interpretación sociológica" Estudios Sociológicos vol.1", Boletín Informativo del Seminario de Derecho Político, Universidad de Salamanca, 1956.

- "Consideraciones en torno al concepto, método y funciones del Derecho Constitucional Comparado", Boletín Informativo del Seminario de Derecho Político, Universidad de Salamanca, nº 6, 1955.

Morodo LEONCIO, R.:

- "Constitución, legalidad, legitimidad", Boletín Informativo del Seminario de Derecho Político de Salamanca n ${ }^{\circ}$ 26, Princeton, 1962.

Ollero, C. :

- "El Derecho Político como Ciencia Política", "La teoría del Estado y el Derecho Constitucional en el sistema del Derecho Político como Ciencia Política", "Ciencia política y Sociología", Estudios de Ciencia Política, Editora Nacional, Madrid, 1955.

- "Resumen sistemático de un intento de reelaboración del Derecho Político", Información Jurídica, n $\mathrm{n}^{\circ}$ 139, 1954.

- «La teoría del Estado y el Derecho constitucional en el sistema de Derecho Político como Ciencia Política", Información Jurídica n ${ }^{\circ}$ 137, 1954.

- Introducción al Derecho Político. La consideración científica de las relaciones entre la sociedad y el Estado, Bosch, Barcelona, 1948. 
- El Derecho constitucional de la postguerra. Apuntes para su estudio, Bosch, Barcelona, 1949.

PÉREZ SERRANO, N:

- "La crisis científica del Derecho Político", Información Jurídica n 42, 1946.

- "Capítulo III. Concepto del Derecho Político", "Capítulo IV. Relaciones del Derecho Político. Método. Plan", Tratado de Derecho Político, 1976.

- "Cien años de Derecho Político (1858-1958)" Discurso. Real Academia de Ciencias Morales y Políticas (con motivo del primer centenario de la misma). Madrid, 1958 (también publicado en Escritos de Derecho Político, Tomo I, Instituto de Estudios de Administración Local, Madrid, 1984).

- "Las ficciones en el Derecho constitucional", Real Academia de Jurisprudencia y Legislación. Madrid, 1948 (también publicado en Escritos de Derecho Político, Tomo I, Instituto de Estudios de Administración Local, Madrid, 1984).

RAMíREZ, M,

- "La ciencia política en España: problemas, métodos y áreas de estudio", Revista de Derecho Público n ${ }^{\circ}$ 67, 1977.

RAMiRo Rico, N.:

- "Breves apuntes críticos para un futuro programa moderadamente heterodoxo del Derecho Político y de su muy azorante enseñanza", Revista de la Opinión Pública, no 37, 1974 (también publicado en El animal ladino y otros estudios politicos, Alianza, Madrid, 1980).

ROMERO, C.E.:

- "Ciencia política, Derecho Político y Derecho Constitucional (aportes didácticos)", Revista de Estudios Políticos, n 185, 1972.

Rubio Llorente, F:

— "Nota preliminar", Stein, E., Derecho Político, Aguilar, Madrid, 1973

Ruiz DEL CASTILlO, C,

- Situación y rumbos del nuevo Derecho Constitucional, 1952.

- "Definición del Derecho Político", Revista de la Facultad de Derecho, Universidad de Madrid, 1942

SÁNCHEZ AgESTA, L:

— "Política y Derecho", Filosofía y Derechos. Estudios en honor del profesor José Corts Grau, Universidad de Valencia, 1977.

- "Las ciencias políticas. Concepto, método, fines, tendencias. Su situación en España", Anuario de la Educación, Madrid, 1974.

- Los campos de investigación de las Ciencias Políticas, Universidad Autónoma de Madrid, 1970.

- Principios de teoría política, Editora Nacional, Madrid, 1966.

- "Crisis de la política como ciencia moral", Revista de Estudios Políticos, n ${ }^{\circ}$ 89, 1965.

- "La política como proceso de comportamiento humano", Revista de Estudios Políticos, 1964.

- "Parte Primera", Derecho constitucional comparado, Editora Nacional, Madrid, 1963. 
- "Las primeras cátedras españolas de Derecho Constitucional", Revista de Estudios Políticos, n 126, 1962,

- "Terminología de las Ciencias Sociales", Revista de Estudios Politicos, n ${ }^{\circ}$ 102/103, 1959.

- "La enseñanza de la Ciencia Política en España", Ponencia presentada en la primera reunión de la Asociación Española de Ciencias Políticas, Ed. Multicopista, 1959.

- "Los orígenes de la Teoría del Estado en el pensamiento español del siglo XVI", Revista de Estudios Politicos, n ${ }^{\circ}$ 98, 1958.

- Teoría y realidad en el conocimiento político, Universidad de Granada, 1945.

- Lecciones de Derecho Político, Imp. $\mathrm{H}^{\circ}$ de Paulino Ventura, Granada, $1943 / 1945$.

— "Valor y eficacia del Derecho Constitucional", Revista de Legislación y Jurisprudencia, Tomo 168, 1935.

SANTAMARÍA, J.:

- "Determinismo y desarrollo" Boletín Informativo de Ciencia Política n 6, 1971.

Tierno Galván, E.:

- "Especificaciones de un Derecho Constitucional para una fase de transición", Boletín Informativo de Ciencia Politica n 10, 1972.

— "Prólogo", Lucas Verdú, P, "Introducción al Derecho Político", Studia Albornotiana. Publicaciones del Real Colegio de España en Bolonia, Barcelona: J.M. Bosch, 1958

- "Recensión a Ollero, C, Estudios de la Ciencia Política, Revista de Estudios Políticos no 81, 1955.

TOMÁs VilLARROYA, J::

- "La dirección dogmática del Derecho Político", Revista de la Administración Pública, $\mathrm{n}^{\circ}$ 79, 1976

VAlle Pascual, L.:

- Principios de Derecho Político I. Derecho político general, Librería General, Zaragoza, 1945.

VALLE, L. DEL:

- Manual de Derecho Político General, Librería General, Zaragoza, 1941.

VILLAROYA, J.T.:

- "La dirección dogmática en el Derecho Político", Revista de Administración Pública, no 79, 1976.

Xifra Heras, J.:

- "El Derecho Político, disciplina enciclopédica", Revista de Estudios Políticos, $\mathrm{n}^{\circ} 153 / 154,1967$.

- Curso de Derecho constitucional, Bosch, Barcelona, 1957.

ZAFRA VALVERDE, J.:

- Teoría fundamental del Estado. Lecciones para un curso de Derecho Politico, Universidad de Navarra, Pamplona, 1957. 
4. ORIENTACiÓN Y MÉTODO DE NUESTRA ASIGNATURA DESDE El SURGIMIENTO DE LA CONSTITUCión de 1978.

AJA FERNÁNDEZ, E.:

- "Derecho Constitucional", Ferreiro, J.J., Miquel, J., La enseñanza del Derecho en España, Tecnos, Madrid, 1987.

- "Estudio preliminar", Lasalle, F, ¿Qué es una Constitución?, Ariel, Barcelona, 1984.

Alonso De ANTONIO, A.L.:

- "Orientación pedagógica de la enseñanza del Derecho Constitucional. Pautas de actuación, objetivos y métodos", VV.AA, Estudios de derecho público en homenaje a Juan José Ruiz-Rico, Tecnos, Madrid, 1997.

Alonso De Antonio, J.A.:

- "Notas sobre la incidencia de la Constitución en la teoría de los principios generales del Derecho", VV.AA, Estudios de derecho público en bomenaje a Juan José Ruiz-Rico, Tecnos, Madrid, 1997.

ALVAREZ VÉlEZ, M.I.:

- "Del Derecho Político al Derecho Constitucional", Boletín de la Facultad de Derecho de la UNED, n 12, 1997.

Alzaga VillaAmil, O.:

- "Capítulo I. El Derecho Político", Derecho Político Español según la Constitución de 1978, Editoriales de Derecho Reunidas, Madrid, 1996 (2ª a $4^{\mathrm{a}}$ edición en Editorial Ramón Areces).

- "En torno a un posible nuevo enfoque de la asignatura denominada Derecho Político", Revista del Departamento de Derecho Político, n. 4, 1979.

Aragón Reyes, M.:

- Encuesta sobre la orientación actual del Derecho Constitucional", Teoría y Realidad Constitucional $\mathrm{n}^{\circ}$ 1, 1998.

- "Un buen ejemplo de Derecho Político español: conversación con el profesor Rodrigo Fernández-Carvajal González", Anuario de Derecho Constitucional y Parlamentario, $\mathrm{n}^{\circ}$ 8, 1996.

- "Introducción", García Pelayo, M, Derecho constitucional comparado, Alianza Editorial, Madrid, 1993.

- "El principio democrático y la reconstrucción teórica del Derecho Público", Constitución y Democracia, 1989.

- "El control como elemento inseparable del concepto de Constitución", Revista Española de Derecho Constitucional n ${ }^{\circ}$ 19, 1987.

- "Constitucionalismo", González Encinar, J.J (ed), Diccionario del sistema político español, Madrid: Akal, 1984.

ARBós, X.:

- "Un apunte acerca de la ciencia del Derecho Constitucional como ciencia social", Revista Vasca de Administración Pública, no 39, 1994.

ASENSI SABATER, J.:

- La época constitucional, Tirant lo Blanch, Valencia, 1998. 
Balaguer Callejón, F.:

- "El Derecho Constitucional", Manual de Derecho Constitucional, Tecnos, Madrid, 2005.

- "Constitución normativa y ciencia del Derecho", VV.AA, Estudios de Derecho público en bomenaje a Juan José Ruiz-Rico, Madrid: Tecnos, vol 1, 1997.

- "Apuntes literarios de Derecho Político reivindicación de los autores olvidados de la teoría constitucional", VV.AA, Estudios de derecho público en bomenaje a Juan José Ruiz-Rico, Tecnos, Madrid, 1997.

BERMEJO, J.L.:

- "Estudio preliminar", Lecciones de Derecho Constitucional de R. SALAs, Centro de Estudios Constitucionales, Madrid, 1982.

Blanco VAlDÉs, R.:

- El valor de la Constitución, Alianza Editorial, Madrid, 1994.

Blasco GiL, Y.:

- "La enseñanza del Derecho Político en Valencia durante la Restauración", La enseñanza de las ideas constitucionales en España e Iberoamérica. Actas del Congreso internacional sobre la enseñanza de las ideas constitucionales, Colección Ideas y Políticas Constitucionales, Valencia, 2001.

Cabo MarTín, C. DE:

- "El elemento utópico, ingrediente cultural del constitucionalismo", Derecho Constitucional y Cultura, Balaguer F., (Coord.), Tecnos, Madrid, 2004.

- "Encuesta sobre la orientación actual del Derecho constitucional", Teoría y Realidad Constitucional $\mathrm{n}^{\circ} 1$, $1^{\mathrm{er}}$ semestre de 1998.

- "La función histórica del constitucionalismo y sus posibles transformaciones", Contra el consenso. Estudios sobre el Estado constitucional y el constitucionalismo del Estado social, Instituto de Investigaciones Jurídicas Universidad Autónoma de México, México, 1997.

- "Capítulo I: El marco metodológico", Teoría histórica del Estado y del Derecho Constitucional vol 1. Formas precapitalistas y Estado moderno, PPU, Barcelona, 1988

- Sobre la función histórica del constitucionalismo y sus posibles transformaciones, Universidad de Salamanca, Salamanca, 1978.

CANDELA, J.:

- "Concepto de Derecho Político (el Derecho Político como Ciencia Política)", Empresas Politicas, n 6, 2005.

CARBONELL, M.:

- Neoconstitucionalismos, Trotta, Madrid, 2003.

CARRERAS, F.:

- "Prólogo", Barceló, M, Derechos y deberes constitucionales en el Estado Autonómico, Cívitas, Madrid, 1991.

Cascajo Castro, J.L.:

- "Constitución y Derecho Constitucional en la Unión Europea", Teoría y Realidad Constitucional $\mathrm{n}^{\circ}$ 15, 2005.

- "Constitución y Derecho Constitucional", Revista Jurídica de Castilla y León, $\mathrm{n}^{\circ}$ extraordinario, 2004. 
Cavero lataillade, I., Zamora Rodríguez, T.:

- "Introducción", Introducción al Derecho Constitucional, Universitas, Madrid, 2005.

CRuZ Villalón, P.:

- "El ordenamiento constitucional: una indagación empírica", La curiosidad del jurista persa y otros estudios sobre la Constitución, Centro de Estudios Políticos y Constitucionales, Madrid, 1999.

- "Posibilidad y cometido de un Derecho constitucional constitucionalmente adecuado", Estudios de derecho constitucional y de ciencia política: Homenaje al profesor Rodrigo Fernández-Carvajal, Universidad de Murcia, Murcia, 1997.

Esteban Alonso, J. DE:

- "Encuesta sobre la orientación actual del Derecho constitucional", Teoría y Realidad Constitucional n ${ }^{\circ}$ 1, 1998.

FERnÁNDEZ CARVAJAL, R.:

- «El Derecho Político y el lugar de lo jurídico en el conocimiento científico de la política", Anuario de Derecho Constitucional y Parlamentario, $\mathrm{n}^{\circ} 15$, 2003.

- "Notas sobre el Derecho Constitucional como nuevo Derecho común", Anuario de Derecho Constitucional y Parlamentario, no 1, 1989 (publicado también en el Homenaje al profesor Juan Roca, Universidad de Murcia, Murcia, 1989).

- El lugar de la Ciencia Política, Universidad de Murcia, Murcia, 1981

FERNÁNDEZ SEGADO, F.:

- "La dimensión axiológica del Derecho Constitucional", Cuadernos de la Cátedra Fadrique Furió Cerol, no 1, 1992.

- Aproximación a la Ciencia del Derecho Constitucional (su concepto, bidimensionalidad, vertiente valorativa, contenido y método), Ediciones Jurídicas, Lima, 1995.

Gallego Anabitarte, A.:

- Formación y enseñanza del Derecho Público en España (1769-2000). Un ensayo crítico, Marcial Pons, Barcelona, 2002.

- "La discusión sobre el método en Derecho Público durante la República de Weimar", Revista Española de Derecho Constitucional n 46, 1996.

- "Las asignaturas de Derecho Político y Administrativo: el destino del Derecho Público español", Revista de Administración Pública, n 100-102, 1983 (también en Homenaje a José Antonio García-Trevijano Fos, AlBiÑana García Quintana, C., (Coord.), Consejo Universitario de Estudios Financieros, Madrid, 1982).

- "Prólogo: Derecho Público, Derecho Constitucional y Derecho Administrativo", MENENDEz ReXACH, A.: La jefatura del Estado en el Derecho Público Español, Instituto Nacional de Administración Pública, Madrid, 1979.

García CANales, M.:

- "Nota sobre el método y los límites de la interpretación en Derecho Constitucional", Estudios de Derecho Constitucional y de Ciencia Política (bo- 
menaje al prof. Rodrigo Fernández Carvajal), Universidad de Murcia, Murcia, 1997.

García Costa, F.M.:

- "Las "lecciones de derecho público constitucional" de Ramón Salas y los orígenes de la ciencia española del derecho constitucional", Empresas políticas, $\mathrm{n}^{\circ}$ 6, 2005.

García DE ENTERRÍA, E.:

- "El Derecho constitucional como Derecho", Revista de Derecho Político, № $15,1982$.

- La Constitución como norma y el Tribunal Constitucional, Cívitas, Madrid, 1981 (puede verse una edición más reciente en Cívitas — Aranzadi, Madrid, 2006).

- "La Constitución como norma jurídica", Predieri, A; García de EnTERría, E (Dirs), La Constitución española de 1978. Un estudio sistemático, Cívitas, Madrid, 1980

GARCía LóPEZ, E.

- "El Derecho Constitucional como un compromiso permanentemente renovado. Conversación con el profesor José Joaquim Gomes Canotilho", Anuario de Derecho Constitucional y Parlamentario, no 10, 1998.

- "Guglielmo Ferrero y el Derecho Constitucional", Debate Abierto, n 10, 1991

García Pelayo, M.:

- "La Constitución", Los estudios de un joven de hoy, Laín EnTralgo, P., (Ed.), F.U.E.-I.C.I., Madrid, 1982; o en Obras completas, Tomo III, Centro de Estudios Constitucionales, Madrid, 1991.

Garrorena Morales, A.:

- "Encuesta sobre la orientación actual del Derecho constitucional", Teoría y Realidad Constitucional n ${ }^{\circ}$ 1, 1998.

- "Cuatro tesis y un corolario sobre el Derecho Constitucional", Revista Española de Derecho Constitucional, $\mathrm{n}^{\circ}$ 51, 1997 (publicado también en Estudios de Derecho Constitucional y de Ciencia Política. Homenaje al profesor Rodrigo Fernández Carvajal, Universidad de Murcia, Murcia, 1997).

Gómez Orfanel, G.:

— "El contenido normativo del Derecho Constitucional", Estado E Direito, n " 12, 1993.

— "Noción del Derecho Constitucional", Estado E Direito, n o 3, 1989.

GONZÁLEZ ENCINAR, J.J.:

- "Derecho del Estado y ciencia del Derecho del Estado", Revista Española de Derecho Constitucional $\mathrm{n}^{\circ}$ 41, 1994.

GonZÁlez-TREvijano SÁNCHEZ, P.J.:

- "Derecho Político y Derecho Constitucional", Revista de la Facultad de Derecho de la Universidad Complutense, $n^{\circ}$ 76, 1989/1990.

GuTIÉRREZ GuTIÉRREZ, I.:

- "Sobre la fuerza normativa de la Constitución", Boletín de la Facultad de Derecho de la Universidad Nacional de Educación a Distancia, $\mathrm{n}^{\circ} 12$, 1997 
JÁuregui Beriartu, G.:

- "Estado, soberanía y Constitución: algunos retos del Derecho constitucional ante el siglo XXI", Revista de Derecho Politico n 44, 1998.

JIMÉNEZ ASENSIO, R.:

- El constitucionalismo. Proceso de formación y fundamentos del Derecho constitucional, Marcial Pons, Barcelona, 2003.

JimÉNEZ CAMPO, J:

- "Contra la Constitución material", VV.AA, Estudios de Derecho Público en bomenaje a Juan José Ruiz Rico, Tecnos, Madrid, 1997.

JiméneZ DE PARGA, M.:

- "El Derecho Político en el tránsito del milenio", Anales de la Real Academia de Ciencias Morales y Políticas, n 80, 2003.

- Cincuenta años de Derecho Político, Real Academia de Jurisprudencia y Legislación, Granada, 2003.

LÓPEZ Aguilar, J.F.:

- Lo constitucional en el Derecho: sobre las ideas de Constitución y orden jurídico, Centro de Estudios Políticos y Constitucionales, Madrid, 1998

LÓPEZ GARRIDO, D.:

- "La crisis no resuelta de las Ciencias Jurídicas y el método en el Derecho Constitucional", Revista Vasca de Administración Pública, n 15, 1986.

LÓPEZ GUERRA, L.:

- "Encuesta sobre la orientación actual del Derecho constitucional", Teoría y Realidad Constitucional $\mathrm{n}^{\circ}$ 1, 1998.

- "Una noción previa del Derecho Constitucional", Introducción al Derecho Constitucional, Tirant lo Blanch, Valencia, 1994.

- «El Derecho Constitucional español. Origen y características de la Constitución", VVAA, Derecho Constitucional, Volumen I, Tirant lo Blanch, Valencia, 1991.

López PinA, A,

- "La dogmática alemana, punto de partida de una teoría del Derecho público. Prolegómena a la edición española", Benda, E; Mainofer, W; Vogel, H; Hesse, K; Heyde, W, Manual de Derecho constitucional, Marcial Pons, Madrid, 1996

- "Doctrina Española de Derecho Constitucional", Debate Abierto. Revista de Ciencias Sociales, no 4, 1991

LuCAS VERDú, P.:

- "La enseñanza del Derecho Constitucional y de su correspondiente método", Anales de la Real Academia de Ciencias Morales y Politicas, $\mathrm{n}^{\circ} 84$, 2007.

- «Una polémica obsoleta o una cuestión recurrente? Derecho constitucional versus Derecho político", Teoría y Realidad Constitucional n 3, 1999.

- La Constitución en la encrucijada (palingenesia iuris politici), Real Academia de Ciencias Morales y Políticas, Madrid, 1994.

- "El Derecho Parlamentario en el arco del Derecho Político", Revista de la Facultad de Derecho de la Universidad Complutense, n 72, 1986/1987. 
- El sentimiento constitucional (Aproximación al estudio del sentir constitucional como modo de integración politica), Reus, Madrid, 1985

- "Derecho Político, Ciencia Política y Derecho Constitucional", Revista de Política Comparada, n $\mathrm{n}^{\circ}$ 10/11, 1984.

- "El Derecho constitucional como Derecho administrativo: la ideología constitucional del prof. García de Enterría", Revista de Derecho Político, $\mathrm{n}^{\circ}$ 13, 1982.

Lucas Verdú, P.; Lucas Murillo de la Cueva, P.:

- "El problema conceptual del Derecho Político", Manual de Derecho Político, Tecnos, Madrid, 1987.

Mellado, F.:

- Tratado Elemental de Derecho Político, Imprenta M.G. Hernández, 1891.

MOlas Batllori, I. :

- "Encuesta sobre la orientación actual del Derecho Constitucional", Teoría y Realidad Constitucional n ${ }^{\circ}$ 1, 1998.

NiETO, A.:

- "Peculiaridades jurídicas de la norma constitucional", Revista de Administración Pública, no 100-102, 1983.

OeHLing Ruíz, H.:

- "Del Derecho Político al Derecho Constitucional: algunos antecedentes como disciplina académica", Manuel Fraga. Homenaje Académico, Vol. II, Fundación Canovas del Castillo, Madrid, 1997.

Oliver Araujo, J.:

- "Algunas reflexiones sobre la asignatura denominada Derecho Constitucional", Politica y Derecho, Tirant lo Blanch, Valencia, 1996.

Ollero, C.:

- "Derecho Político, Ciencia Política y Derecho Constitucional", Revista de Politica Comparada, n $\mathrm{n}^{\circ}$ 10/11.

OTTO Y PARDO, I.:

— "La Constitución abierta", Revista de Occidente n 54, 1985.

Peláez Albendea, M.:

- "La cátedra de Derecho Político de la Universidad de Sevilla (1900-1942) (1ª parte), Empresas Politicas, n ${ }^{\circ} 2,2003$.

PeÑa GONZÁlEZ, J.:

— "El Derecho Político", Derecho y Constitución, Dykinson, Madrid, 2004.

Pérez Calvo, A.:

- "Reflexiones generales en torno al Derecho Constitucional", Huarte de San Juan $\mathrm{n}^{\circ}$ 1, 1994.

PÉREZ ROYO, J.:

- "El Derecho Constitucional en la formación del jurista", Revista Española de Derecho Constitucional, $\mathrm{n}^{\circ}$ 46, 1996 (publicado también en Curso de Derecho Constitucional, Marcial Pons, Madrid, 1997).

- "Del Derecho Político al Derecho Constitucional: Las garantías constitucionales", Revista del Centro de Estudios Constitucionales, n 12,1992. 
- "Recensión: E. García de Enterría: La Constitución como norma y el Tribunal Constitucional, Cívitas, Madrid, 1981", Revista de Estudios Políticos, $\mathrm{n}^{\circ} 25,1982$.

PÉREZ SERRANO, N.:

- "Concepto, método y fuentes del Derecho político", Revista de Derecho Político $\mathrm{n}^{\circ}$ 95, 1984 (también publicado en Escritos de Derecho Político, Instituto de Estudios de Administración Local, Madrid, 1984).

Pérez-SERRANo JÁuregui, N.:

- "Memoria explicativa de la asignatura Derecho Constitucional español", Revista de las Cortes Generales, n 37, 1996.

Peset Reig, M., García Trobat, P.:

- "La Constitución de 1812 o cómo educar a un pueblo", La enseñanza de las ideas constitucionales en España e Iberoamérica, SÁnchez FerRIz, R., GARCía PeChú́n, M., 2001.

- "Las primeras cátedras de constitución" Cuadernos del Instituto Antonio de Nebrija de Estudios sobre la Universidad Carlos III, 1, 1998.

Porras NADALES, A.J.:

- "Derecho Constitucional y evolucionismo jurídico", Revista de Estudios Políticos, $\mathrm{n}^{\circ} 87,1995$.

PORTERO MOLINA, J.A.:

- "Algunas cuestiones en el Derecho Político español. 1875-1900", Revista de Estudios Políticos, no 18, 1980.

PORRAS RAMÍrEZ, J.M.:

- "Breve historia de la formación y evolución del Derecho constitucional, con particular referencia a su desarrollo en España", Morodo, R; VEGA, P. DE (Dirs), Estudios de Teoría del Estado y Derecho constitucional en bonor a Pablo Lucas Verdú, Tomo II, Universidad Complutense - UNAM, Madrid/México, 2001.

- "Derecho Constitucional y evolucionismo jurídico", Revista de Estudios Políticos, no 87, 1995.

PunseT, R.:

- "Los primeros veinte años de la ciencia española del Derecho Constitucional", Revista de Estudios Politicos, no 108, 2000.

Rodríguez Aísa, M.L.:

- "Algunas cuestiones actuales planteadas a la disciplina del Derecho Político", ICADE. Revista de las Facultades de Derecho y Ciencias Económicas y Empresariales, n ${ }^{\circ}$ 10, 1987.

RODRÍGUEZ ZAPATA, J.:

— "El Derecho Constitucional", Teoría y Práctica del Derecho Constitucional, Tecnos, Madrid, 1996.

Rubio Llorente, F.:

- "La Constitución como fuente del Derecho", La forma del poder. Estudios sobre la Constitución, Centro de Estudios Políticos y Constitucionales, Madrid, 1997. 
- "Derecho Constitucional", Enciclopedia Jurídica Básica, II, Cívitas, Madrid, 1995.

- «El Derecho Constitucional como vocación y como oficio (entrevista de A. Garrorena Morales)", Anuario de Derecho Constitucional y Parlamentario, $\mathrm{n}^{\circ} 1,1989$.

- "Prólogo", Pizzorusso, A., Lecciones de Derecho Constitucional, Centro de Estudios Constitucionales, Madrid, 1984.

Ruiz Huerta Carbonell, A.:

- «La enseñanza de la Constitución en España. Por una cultura constitucional", Revista Jurídica de Castilla y León, no extraordinario, 2004.

Ruíz Miguel, C.:

- "Recensión: P. LuCAS Verdú, La Constitución en la encrucijada (palingenesia iuris politici), Real Academia de Ciencias Morales y Políticas, Madrid, 1994", Revista de Estudios Políticos, n 86, 1994.

SÁnCHEz Agesta, L.:

- "La noble obra científica de un gran maestro", Revista Española de Derecho Constitucional, $\mathrm{n}^{\circ}$ 12, 1984.

- "Las cinco grandes preguntas de la Filosofía y la Ciencia Política", Homenaje al profesor García Pelayo, Madrid, 1979.

- "La Ciencia Política y el análisis del proceso de decisión", Revista de la Facultad de Derecho de la Universidad Complutense de Madrid, $\mathrm{n}^{\circ} 71$, 1978 (también en Real Academia de Ciencias Morales y Politicas, Madrid, 1978).

SÁNCHEZ FERRIZ, R.:

- "A modo de premisa. Política y Derecho al despuntar el tercer milenio", El Estado Constitucional y su sistema de fuentes, Tirant lo Blanch, Valencia, 2005 (también en Introducción al Estado Constitucional, Ariel, Barcelona, 1993).

- "Aproximación a la difusión de las ideas constitucionales en España y su configuración como disciplina jurídica en el siglo XIX", La enseñanza de las ideas constitucionales en España e Iberoamérica, SÁNCHEz FERRIz, R., GARCía PeChú́n, M., 2001.

SANTAOLALLA LÓPEZ, F.:

- "Derecho y Derecho Constitucional", Derecho Constitucional, Dykinson, Madrid, 2004.

- "La función de control y la ciencia del Derecho constitucional", Revista de las Cortes Generales, no 12, 1987.

SOLOZÁBAl ECHAVARRÍA, J.J,

- Principialismo y orden constitucional, Institut de Ciències Polítiques i Socials, Barcelona, 1998

- "Sobre el contexto histórico-intelectual del positivismo jurídico", Revista de Estudios Políticos, no 48, 1985.

Tajadura Tejada, J.:

- El Derecho Constitucional y su enseñanza, Instituto Iberoamericano de Derecho Constitucional, Lima, 2001. 
VARELA SuANZES, J.:

- "Qué ocurrió con la Ciencia del Derecho Constitucional en la España del siglo XIX?", Boletín de la Facultad de Derecho, n 14, 1999.

- "QQué ocurrió con la Ciencia del Derecho Constitucional en la España del siglo XIX?", Anuario de Derecho Constitucional y Parlamentario, no 9 , 1997.

Vega García, P. DE:

- "El tránsito del positivismo jurídico al positivismo jurisprudencial", Teoría y Realidad Constitucional n $\mathrm{n}^{\circ} 1,1998$.

- "En torno al concepto político de Constitución", García Herrera, M.A, El constitucionalismo en la crisis del Estado social, Servicio Editorial de la Universidad del País Vasco, Bilbao, 1997.

- "Prólogo", Schmitt, C, La defensa de la Constitución, Madrid, Tecnos, 1983.

VillacorTa MANCEBO, L.:

- "Derecho Constitucional y método: algunas consideraciones desde la perspectiva de la teoría estructuradora de las normas", Estudios de Derecho Público en bomenaje a Juan José Ruíz-Rico, Tecnos, Madrid, 1997.

- "Algunas transformaciones en la concepción y el método del Derecho: sus implicaciones para el Derecho constitucional", Anuario de la Facultad de Derecho de Alcalá de Henares, n 3/4, 1993/1994.

VVAA:

- Constitución y constitucionalismo boy, Fundación Manuel García Pelayo, Venezuela, 2000.

5. SemblanZas de PROFESORES y ESTUdiosos DE NUESTRA ASIGNATURA.

ARAGÓn ReYES, M.:

- «Entrevista al Prof. Rodrigo Fernández-Carvajal. Un buen ejemplo del Derecho Político español", Anuario de Derecho Constitucional y Parlamentario, $\mathrm{n}^{\circ}$ 8, 1996.

- "Introducción", García Pelayo, M: Derecho Constitucional Comparado, Alianza Editorial, Madrid, 1993.

ArRoyo JimÉnEZ, L.:

— "Vicente Santamaría de Paredes", Parlamento y Constitución n 8, 2004.

Ayuso, M.:

- "El Derecho Político de Francisco Elías de Tejada", Empresas politicas, n 2, 2003.

Begué CANTÓN, O.:

- "Perfil y memoria de García-Pelayo", Constitución y constitucionalismo boy, VVAA, Fundación Manuel García Pelayo, Venezuela, 2000.

Belda Pérez Pedrero, E.:

— "Luis Sánchez Agesta”, Parlamento y Constitución n 3, 1999. 
Blasco Gil, Y., Correa Ballester, J.:

- "Francisco Javier Conde García, una cátedra de Derecho Político en una España sin Constitución", Presente y futuro de la Constitución Española de 1978, Tirant lo Blanch, Valencia, 2005.

Cascajo Castro, J.L.:

- "Dos grandes maestros del Derecho político español (M. García Pelayo E. Tierno Galván)", Debate Abierto n 10, 1991.

Cruz Villalón, P.:

— "Biografía intelectual de Tomás y Valiente", Revista Española de Derecho Constitucional n $\mathrm{n}^{\circ}$ 50, 1987.

DíAz-Revorio, F.J.:

— "Nicolás Pérez Serrano", Parlamento y Constitución n 1, 1997.

— "Adolfo Posada", Parlamento y Constitución n ${ }^{\circ}$ 2, 1998.

— "Juan Donoso Cortés", Parlamento y Constitución no 3, 1999.

Elías de TeJada, F.:

- "Diego Lopes Rebelo, nuestro más antiguo tratadista en Derecho Político", Revista de Estudios Políticos, no 25/26, 1946.

FERNÁNDEZ-CARVAJAL, R.:

- "Las constantes de Donoso Cortés", Revista de Estudios Políticos n ${ }^{\circ} 95$, 1957

García Costa, F. M.:

- La ciencia española del Derecho político constitucional en sus textos (18081939), Tirant lo Blanch, Valencia, 2008.

Garrorena Morales, A.:

— "Rodrigo, maestro", Estudios de derecho constitucional y de ciencia politica : homenaje al profesor Rodrigo Fernández-Carvajal, 1997.

- "Estudio preliminar", Alcalá Galiano, A, Lecciones de Derecho Político, Centro de Estudios Constitucionales, Madrid, 1984.

- El Ateneo de Madrid y la teoría de la monarquía liberal (1836-1847), Instituto de Estudios Políticos, Madrid, 1974.

Guillén Kalle, G.:

- "Francisco Ayala, del Derecho Político a la Sociología", Empresas Políticas, $n^{\circ} 2,2003$.

Guillén Kalle, G. Almoguera Carreres, J.:

- "De Ihering a Martínez Marina: el sendero intelectual de Adolfo Posada a través de sus estudios preliminares", Revista de las Cortes Generales, n 67 , 2006.

JimÉNEZ SEgADO, M.:

- "Manuel García-Pelayo, jurista político", Empresas políticas, no 2, 2003.

LEGAZ LACAMBRA, L.:

- "Javier Conde: el hombre, el intelectual, el político", Anales de la real Academia de Ciencias Morales y Políticas, $\mathrm{n}^{\circ}$ 52, 1975.

LÓPEZ PINA, A.:

- "Manuel García Pelayo (1909-1991): un catedrático de Derecho político beligerante", 20 Juristas del siglo XX, ABZ Editores, México, 2000. 
LuCAS VERDú, P.:

- La aventura política de D. Antonio Alcalá Galiano, su aportación al Derecho Político Constitucional", Anales de la Real Academia de Ciencias Morales y Políticas, $\mathrm{n}^{\circ}$ 79, 2002.

MANCEBO, M.F.:

- «El Derecho Político en Valencia, con especial referencia a Mariano Gómez González (1915-1932)", La enseñanza del Derecho en el siglo XX. Homenaje a Mariano Peset, MorA, A., (Coord.), Biblioteca Antonio Lebrija, Madrid, 2004.

MARTín, S.:

- "Fe católica y razón liberal en el Derecho Político. La anónima relevancia de Juan de Dios Vico y Bravo (1845-1908)", La enseñanza del Derecho en el siglo XX. Homenaje a Mariano Peset, MorA, A., (Coord.), Biblioteca Antonio Lebrija, Madrid, 2004.

MARTínez NeIRA, M.:

- "La cuestión pedagógica. Adolfo Posada y la enseñanza del Derecho", Aulas y saberes. VI Congreso Internacional de las Universidades Hispánicas, Universitat de Valencia, 2003.

Molina Cano, J.:

— Estudio preliminar. Un anticipador de la Constitución política española. Las posiciones jurídico-políticas de Javier Conde", CONDE, J, Introducción al Derecho Político Actual, Comares, Granada, 2006.

- "Estudio preliminar. Javier Conde, jurista de Estado", Conde, J, Teoría y sistema de las formas politicas, Comares, Granada, 2006.

- "El Derecho Político en Ignacio María de Lojendio", Empresas Políticas, n 6, 2005.

- "La Ciencia Política de Rodrigo Fernández-Carvajal", Empresas Políticas, n 2, 2003.

— "Javier Conde y el realismo político", Razón Española n 100, 2000.

Monereo PÉrez, J.L.:

- "El pensamiento juridico político de Adolfo Posada", Posada, A., Tratado de Derecho Político, Comares, Barcelona, 2003.

PÉREZ AlBendea, M.:

- "Mariano Latre Juste, filósofo de la política y sus escritos de Derecho Político", Estudios de Derecho Público en Homenaje a Juan José Ruíz Rico, Tecnos, Madrid, 1997.

Pérez-SERrano Jauregui, N.:

— "Nicolás Pérez Serrano (1890-1961). Semblanza y datos biográficos", Teoría y Realidad Constitucional $\mathrm{n}^{\circ}$ 18, 2006.

Portero Molina, J.A,

- "El Derecho Político en la obra de Fernando de los Ríos", Sistema. Revista de Ciencias Sociales, no 152/153, 1999.

ReBATO PeÑo, E.:

— "Carlos Ruiz del Castillo", Parlamento y Constitución n 4, 2000.

— "Antonio Alcalá Galiano", Parlamento y Constitución n 3, 1999. 
— "Fernando de los Ríos Urruti", Parlamento y Constitución n 2, 1998.

— "Enrique Tierno Galván", Parlamento y Constitución n ${ }^{\circ}$ 1, 1997.

Ruiz Miguel, C.:

- "Nicolás Pérez Serrano, maestro pionero del Derecho Constitucional español", Empresas Politicas, n 2, 2003.

Ruíz Robledo, A.:

- "Apuntes literarios de Derecho Político o reivindicación de los autores olvidados de la teoría constitucional", Estudios de Derecho Público en homenaje a Juan José Ruíz Rico, Tecnos, Madrid, 1997.

SÁInZ Moreno, F.:

- "Recensión a Eduardo García de Enterría, La Constitución como norma jurídica y el Tribunal Constitucionab, Revista Española de Derecho Constitucional $\mathrm{n}^{\circ}$ 6, 1982

SÁNCHEZ Agesta, L.:

- "Las primeras cátedras españolas de Derecho constitucional", Revista de Estudios Políticos, no 163, 1963.

Valero Fernández de Palencia, A; Peláez, MJ.:

— "Conde García, Francisco Javier (1908-1974)", Peláez, M.J (Ed), Diccionario crítico de juristas españoles, portugueses y latinoamericanos, Madrid: Marcial Pons, 2004

VARela SuAnZes, J.:

- "El Derecho Político de Adolfo Posada", Estudios de Teoría del Estado y Derecho Constitucional en honor de Pablo Lúcas Verdú, Morodo, R., De VegA, P., (Coords.), vol. 1, Universidad Complutense, Madrid, 2001.

- "El Derecho Político de Adolfo Posada", Revista Jurídica de Asturias, n 23,1999 .

VELARDE FUERTES, J.

— «Rodrigo Fernández-Carvajal», Veintiuno n 35, 1997

VIDAL MARÍN, T.:

— "Torcuato Fernández Miranda y Hevia", Parlamento y Constitución no 3, 1999.

- "Joaquín Francisco Pacheco y Gutiérrez Calderón", Parlamento y Constitución $\mathrm{n}^{\circ}$ 3, 1999.

— "Manuel García Pelayo", Parlamento y Constitución n n $^{\circ} 1997$.

VILLAROYA, J.T.:

- "Alcalá Galiano entre dos destierros", Revista del Instituto de Ciencias Sociales, n 8, 1966.

VV.AA.:

- "Semblanzas y recuerdos de Carlos Ollero", Revista de Ciencias Sociales. Debate Abierto. Volumen bomenaje al prof. Carlos Ollero (I), n ${ }^{\circ}$ 10, 1994

ZAPATERO, V. et alii:

- Fernando de los ríos, intelectual y político, Universidad de Granada, Granada, 1997. 
ABSTRACT. This Repertoire includes the works that has been published about orientation and method of Constitutional right along the history of our discipline: before 1900, from 1900 until the end of the II Republic, during Franco's dictatorship and from the approval of the Constitution of 1978. It is included, lastly, a section that picks up those panoramics carried out professors and studious of our subject. 